country. This was a new post as the traffic manager had up to this time been in London and under the direction of the London manager. In the new position he would be his own master responsible only from time to time to the director.

The patient's manner of talking had quite changed. He was alert and confident, and gave the impression that he was no longer satisfied with a routine subordinate post, but was desirous of having a responsible post requiring initiative and independence.

In January, 1950, he wrote to say that he was facing up to the problems and difficulties of his new post with confidence. On February 1, 1950, his brother reported that he had seen him recently and that he was satisfied that he had made a good recovery. He observed no difference in his personality before and after the accident ; he thought that his brother had regained his former confidence in his ability to do his work, and that he now had the same energy and initiative as before. His relations with other people were still good.

\section{Summary}

A case of heart arrest during anæsthesia is reported with special reference to the mental state during recovery. One year after the accident the patient showed signs suggestive of a mild frontal lobe syndrome. Two years after the accident he appeared to have made a good recovery and his brother could see no change of personality since the illness. There was still amnesia for 12 hours before and four days after the accident.

Thanks are expressed to the County Medical Officer, London County Council, for permission to publish this case ; to Dr. H. Hilton Stewart of Claremont Street Hospital for Nervous Diseases, Belfast, for the electroencephalogram ; and to Dr. R. S. Allison, Physician-incharge, Neurological Department, Royal Victoria Hospital, Belfast, for his help and encouragement in preparing this paper.

\section{REFERENCES}

Bailey, H. (1947). Lancet, 1, 5.

Howkins, J., McLaughlin, C. R., and Daniel, P. (1946). Ibid., 1, 488.

Noble, A. B. (1947). Canad. med. Ass. J., 56, 490.

Sappenfield, R. S., and Adriani, J. (1947). Sth. Med. J., 40, 455 .

\title{
INTERNATIONAL FEDERATION OF E.E.G. SOCIETIES
}

The International Federation of E.E.G. Societies was founded in the form of an International Committee at a meeting in London in July, 1947. The journal Electroencephalography and Clinical Neurophysiology was established as the organ of the Federation, and working committees were formed. At a second meeting in Paris in 1949 a more formal organization was established in liaison with UNESCO. Correspondence should be addressed to the Secretary (Dr. H. Gastaut), International Federation of Electro-encephalography and Clinical Neurophysiology, 149 Prom. de la Corniche, Marseille, France.

The next meeting of the Federation will be held in the United States in June, 1952.

Correction.-On page 46 of the February issue the reference to Ferner, H. (1940). Z. Anat. EntwGesch., 110, 391, is wrong, and the full correct reference is : Ferner, H. (1949). "Die Trigeminuszisterne und ihre praktische Bedeutung für die Alkoholinjektion in das Gassersche Ganglion ", Nervenarzt, 20, 26.

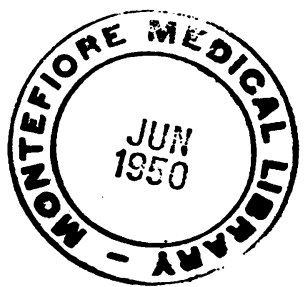

